\title{
Changes in photosynthetic carbon allocation in algal assemblages of Arctic sea ice with decreasing nutrient concentrations and irradiance
}

\author{
Thomas Mock*, Rolf Gradinger \\ Sonderforschungsbereich 313 an der Universität Kiel, Heinrich-Hecht-Platz 10, 24118 Kiel, Germany, \\ and Institute for Polar Ecology, Wischhofstr. 1-3, Gebäude 12, 24148 Kiel, Germany
}

\begin{abstract}
Photosynthetic carbon assimilation into protein, low-molecular-weight metabolites (LMWM), polysaccharides, total lipids and into 3 lipid classes (neutral lipids, glycolipids and phospholipids) was determined in batch-culture experiments with natural assemblages of Arctic-ice algae under simulated in situ irradiance. Photosynthate allocation in 3 parallel batch incubations revealed a high contribution of lipid assimilation to total particulate carbon production $(54.6 \pm 0.4 \%)$ followed by LMWM $(35.0 \pm 1.0 \%)$, carbohydrates $(7.3 \pm 0.1 \%)$ and proteins $(3.0 \pm 0.8 \%)$. Total lipids were mainly composed of glycolipids $(67.4 \pm 3.5 \%)$ with a relatively lower allocation into phospholipids $(28.1 \pm 6.7 \%)$ and neutral lipids $(4.5 \pm 3.2 \%)$. Nutrient addition (final concentrations: $\mathrm{Si}(\mathrm{OH})_{4}=65.5 \pm$ $0.4 \mu \mathrm{mol} \mathrm{l}{ }^{-1}, \mathrm{NO}_{3}=42.9 \pm 0.6 \mu \mathrm{mol} \mathrm{l}^{-1}, \mathrm{PO}_{4}=2.6 \pm 0.0 \mu \mathrm{mol} \mathrm{l}^{-1}$ ) caused algal community growth of $0.22 \pm 0.0 \mathrm{~d}^{-1}$ until nutrients became limiting $10 \mathrm{~d}$ later. $\mathrm{Si}(\mathrm{OH})_{4}: \mathrm{NO}_{3}$ ratios and $\mathrm{NO}_{3}: \mathrm{PO}_{4}$ ratios in the cultures decreased from initially $1.5 \pm 0.0$ to $0.2 \pm 0.1$ and $16.8 \pm 0.2$ to $1.2 \pm 0.5$, respectively. During the first few days of incubation, relative proportions of carbon production for proteins increased 3-fold (max. $11.1 \pm 1.0 \%$ ), those for LMWM 1.5-fold (max. $45.7 \pm 6.4 \%$ ), whereas lipids decreased (min. $32.0 \pm 0.4 \%$ ). Increasing relative proportions of carbon production for carbohydrates were only observed at the end of exponential growth (max. $12.9 \pm 1.3 \%$ ). A dramatic increase of lipids was measured under nutrient depletion (max. $70.9 \pm 3.6 \%$ ) after Day 10, which was the result of glycolipid production, while protein and carbohydrate production decreased to values below $5 \%$ of total particulate carbon production. LMWM also attained lower incorporation rates under nutrient depletion (min. $23.5 \pm 1.1 \%$ ). Production of glycolipids during exponential algal growth is attributed to an acclimation to decreasing irradiance as a consequence of an increase in algal biomass. Decreasing particulate carbon:chlorophyll a ratios during the experiment indicate a physiological response to a reduction in irradiance with simultanous glycolipid production. Glycolipids are the main lipid class in chloroplasts, and especially in thylakoidmembranes, which are strongly developed during low-light acclimation. Excess light energy during stationary algal growth after Day 10 is dissipated in the form of glycolipids and/or neutral lipids. But the latter are probably more significant under high-light conditions.
\end{abstract}

KEY WORDS: Arctic $\cdot$ Sea ice $\cdot$ Algae $\cdot$ Assimilation $\cdot$ Photosynthetic carbon allocation $\cdot$ Nutrient deficiency $\cdot$ Proteins $\cdot$ Carbohydrates $\cdot$ Lipids $\cdot$ Glycolipids

Resale or republication not permitted without written consent of the publishe

\section{INTRODUCTION}

Sea-ice algae are known to have an important function in polar marine ecosystems as contributors to total primary production (Arrigo et al. 1997, Gosselin et al.

*Present address: Alfred Wegener Institute for Polar and Marine Research, Am Handelshafen 12, 27570 Bremerhaven, Germany. E-mail: tmock@awi-bremerhaven.de
1997); however, their contribution is possibly still underestimated (Mock \& Gradinger 1999). Primary production of ice algae is mainly dependent on the photon-flux density (PFD) (Cota 1985, Sullivan et al. 1985, Cota \& Sullivan 1990, Gleitz \& Kirst 1991, Mock \& Gradinger 1999) which is affected by sea-ice thickness and the overlying snow cover (Maykut 1985 Mock \& Gradinger 1999). The net growth of ice algae is also dependent on ice temperature (Bunt 1968, 
Palmisano \& Sullivan 1982, Kottmeier \& Sullivan 1988), salinity (Bates \& Cota 1986, Bartsch 1989, Fiala \& Oriol 1990, Kirst \& Wiencke 1995, Taguchi \& Smith 1997) and essential nutrients (Maestrini et al. 1986, Demers et al. 1989, Syvertsen \& Kristensen 1993, Taguchi \& Smith 1997, Smith et al. 1997).

The biochemical composition of micro-algae is a product of the interplay between the supply of energy from photosynthesis and the synthetic capacity of the cell (Smith et al. 1989). Balanced growth only occurs if the energy input is equivalent to the synthetic capacity of the cell. This is the case for steady state growth, which possibly does not exist under the unstable conditions typical in nature (Smetacek 1996). Photosynthate allocation to lipids and carbohydrates in phytoplankton as well as ice algae varies directly with the availability of light (Smith \& Morris 1980, Li \& Platt 1982, Smith et al. 1989, 1993, 1997, Smith \& Herman 1992) and nutrients (e.g., Palmisano \& Sullivan 1985, Maestrini et al. 1986, Smith et al. 1987, 1993, 1997 , Smith \& Herman 1992, Taguchi \& Smith 1997), this is also evident in temperate phytoplankton (Iwamoto et al. 1955, Fogg 1959, Opute 1974, Li et al. 1980, Shifrin \& Chisholm 1981, Tadros \& Johansen 1988). Low-light conditions, for example stimulate the dominance of glycolipids, which are important structural components of chloroplast membranes as a consequence of shade acclimation (Pohl \& Zurheide 1979, Harwood \& Jones 1989, Klyachko-Gurvich et al. 1999). In contrast high-light conditions and nutrient limitation stimulate the production of storage products such as neutral lipids and carbohydrates, whereas chloroplasts are reduced. Shade-adapted Arctic-ice algae (Cota 1985) have typically low protein and high lipid content (Smith et al. 1989, Cota \& Smith 1991, Smith \& Herman 1992). This biochemical peculiarity may reflect factors controlling algal productivity.

Studies of carbon distribution among photosynthetic end products with respect to different lipid classes in ice algae are few. Investigations by Palmisano et al. (1988) showed higher synthesis of neutral lipids in the later stage of the vernal ice algal bloom. This pathwaychange was interpreted as a response to improved light availability and/or limited nutrient supply (Smith et al. 1997, Taguchi \& Smith 1997). On the basis of past investigations, we hypothesise that decreasing nutrient concentrations under low-light conditions may result in clearly different photosynthetic carbon allocation than under sufficient light intensities.

\section{MATERIALS AND METHODS}

Experimental set-up. The experiment was conducted during RV 'Polarstern' expedition ARK XIII/
$1 \mathrm{a}+\mathrm{b}$ in May/June 1997. Sea-ice micro-algae were collected from a first-year ice floe (Stn 140) at $77^{\circ} 10.2^{\prime} \mathrm{N}, 34^{\circ} 04.4^{\prime} \mathrm{E}$ in the Barents Sea with a $9 \mathrm{~cm}$ SIPRE ice auger. Only the bottom $5 \mathrm{~cm}$ of 33 ice cores, containing the highest algal density, were split into 3 clean 501 polyethylene containers and transported back to the ship. The 11 ice segments in each container were then placed in 201 of $0.2 \mu \mathrm{m}$ pre-filtered sea water and melted at a light intensity of $7 \mu \mathrm{mol}$ photons $\mathrm{m}^{-2} \mathrm{~s}^{-1}$ at $0^{\circ} \mathrm{C}$ to avoid osmotic stress during the melting procedure (Garrison \& Buck 1986). After melting (ca $24 \mathrm{~h}$ ), $9 \mathrm{l}$ of each stock culture were filtered through a $100 \mu \mathrm{m}$ sieve to exclude large grazers and then filled into transparent clean polycarbonate bottles (20 l) and diluted with additional $11 \mathrm{l}$ of $0.2 \mu \mathrm{m}$ filtered sea water at $0^{\circ} \mathrm{C}$. These 3 ice algal batches were held at $-1.0 \pm$ $0.5^{\circ} \mathrm{C}$ (mean $\pm \mathrm{SD}$ ) and a salinity of 32.4 . Continuous illumination during the experiment was provided from above using cool-white fluorescent tubes (Philips TL 33). Total photosynthetically active radiation (PAR) was measured with a $4 \pi$-sensor (Li 193SB) directly at the surface $\left(19.8 \mu \mathrm{mol}\right.$ photons $\left.\mathrm{m}^{-2} \mathrm{~s}^{-1}\right)$ and the bottom $\left(9.3 \mu \mathrm{mol}\right.$ photons $\left.\mathrm{m}^{-2} \mathrm{~s}^{-1}\right)$ of the batch cultures. After an acclimation time of $3 \mathrm{~d}$, the cultures were enriched with a nutrient mixture (von Storch \& Drebes 1964). The bottles were kept closed with a cotton plug during the experiment, and each batch was carefully shaken once a day. Time intervals for subsampling were from 2 to $5 \mathrm{~d}$. At the end of the experiment, no more than ca $30 \%$ of the initial volume had been taken. Brine salinity was calculated according to Assur (1958) and the in situ nutrient concentrations were normalised to brine salinity (Gleitz et al. 1995).

Chemical parameters and pigments. Nutrient concentrations were immediately determined after sampling according to the standard sea water procedures of Grasshoff et al. (1983). For determination of algal pigment concentration (chlorophyll a [chl a] and phaeopigments [phaeo]), subsamples were filtered through Whatman GF/F filters and analysed fluorometically with a Turner Design Model 10-AU digital fluorometer (Arar \& Collins 1992).

The $\mathrm{pH}$ of the batch cultures was determined with a pH-meter (WTW, pH 191), which was calibrated daily with standard buffer solutions.

For particulate organic carbon (POC) and nitrogen (PON) analysis, subsamples were filtered through precombusted Whatman GF/F filters. These filters were kept frozen at $-30^{\circ} \mathrm{C}$ for further processing in Kiel. The thawed filters were acidified for $24 \mathrm{~h}$ with fuming $\mathrm{HCl}(37 \%)$ to dissolve inorganic carbon and finally dried $\left(12 \mathrm{~h}\right.$ at $\left.60^{\circ} \mathrm{C}\right)$. The filters were then transferred to a pewter foil and combusted in oxygenenriched helium atmosphere in a Haereus CHN-ORapid analyzer. 
Algal carbon biomass, species composition and growth. Subsamples of each batch culture were fixed with borax-buffered formalin ( $\%$ final concentration). These samples were stored in the dark at approximately $+10^{\circ} \mathrm{C}$ and counted in Kiel within 7 mo.

Microscopical analyses were carried out with an inverted Zeiss Axiovert 35 microscope according to Utermöhl (1958). Of each sample, 2.97 to $10 \mathrm{ml}$ were concentrated by settling for $48 \mathrm{~h}$ and counted at 200 to $1000 \times$ magnification. Species were determined after Gran (1904), Husted (1966), Throndsen (1970, 1974), Medlin \& Priddle (1990), Crawford et al. (1994), Ikävalko \& Gradinger (1997), and von Quillfeld (1997). For further analyses, all species were grouped into different size classes at genus level. Cell volumes (CV) were calculated using geometric figures, which concurred with the different algal cells. Conversion of CV to cell carbon followed the recommendations of the Baltic Marine Environment Protection Commission (1988).

Maximum growth rates $\left(\mu_{\max }\right)$ under nutrient-replete conditions were calculated using cell counts according to the equation $\mu_{\max }=\ln \left(N_{2} / N_{1}\right) /\left(t_{2}-t_{1}\right)$, where $\mu=$ doublings $\mathrm{d}^{-1} ; N=$ algal abundance $\mathrm{ml}^{-1}$; and $t=$ time, $\mathrm{d}^{-1}$ ).

Production of macromolecular and lipid classes. For the production measurements, 4 parallel samples (each $100 \mathrm{ml}$ ) of each batch culture were dispensed into $100 \mathrm{ml}$ glass flasks and inoculated with $400 \mathrm{\mu l}$ $(100 \mu \mathrm{Ci}) \mathrm{NaH}^{14} \mathrm{CO}_{3}$ (Amersham International plc, Little Chalfont, UK). Three inoculated bottles were used for the light incubations and 1 to determine the dark fixation of the tracer. All samples were incubated for $5 \mathrm{~h}$ at $-1 \pm 0.5^{\circ} \mathrm{C}$ and $9.3 \mu \mathrm{mol}$ photons $\mathrm{m}^{-2} \mathrm{~s}^{-1}$. A concentration of $25 \mathrm{mg} \mathrm{DIC}^{-1}$ (DIC = dissolved inorganic carbon) was used to calculate primary production.

For the determination of total production, $15 \mathrm{ml}$ of each sample were acidified with $150 \mu \mathrm{l}$ of $1 \mathrm{~mol} \mathrm{l}^{-1} \mathrm{HCl}$ $(\mathrm{pH}<2)$ after $5 \mathrm{~h}$. Non-fixed ${ }^{14} \mathrm{C}$ was removed by bubbling with air for $20 \mathrm{~min}$. Ten $\mathrm{ml}$ of this solution were filled into $20 \mathrm{ml}$ plastic vials and mixed with $10 \mathrm{ml}$ Lumagel scintillation cocktail (Baker). The remaining $85 \mathrm{ml}$ was filtered through Whatman GF/F filters. Exudation was measured in $15 \mathrm{ml}$ of the filtrate as in the total production measurements. The filters were washed twice with $20 \mathrm{ml}$ of $0.2 \mu \mathrm{m}$ filtered sea water and transferred into glass centrifuge tubes. The differential extraction of macromolecular classes was performed according to Li et al. (1980). These methods result in a crude fractionation of cellular constituents into protein (TCA-insoluble), polysaccharide (TCAsoluble), lipid (chloroform-soluble) and low-molecularweight-metabolites (LMWM) (methanol-water-soluble). An average of $91 \pm 8 \%$ of the total label was recovered during these extractions. The amount of label recovered in each fraction is reported as the percentage of the sum of the 4 fractions.
For the determination of the labelled phospholipids, glycolipids and neutral lipids, a subsample $(1 \mathrm{ml})$ of the lipid fraction recovered as described above, was dried under $\mathrm{N}_{2}$-atmosphere and then re-dissolved in $1 \mathrm{ml}$ chloroform. This solution was transferred to a $0.5 \mathrm{~g}$ column of activated $\left(4 \mathrm{~h}, 110^{\circ} \mathrm{C}\right)$ silica acid, which had been previously washed with $4 \mathrm{ml}$ chloroform. The column consisted of a glass disposable Pasteur pipette containing a glass-wool plug. The total lipid was separated into neutral lipid, glycolipid and phospholipid fractions by consecutive flushing with $5 \mathrm{ml}$ chloroform, $10 \mathrm{ml}$ acetone and $5 \mathrm{ml}$ methanol (Guckert et al. 1985). The fractions were evaporated to dryness and counted with $10 \mathrm{ml}$ Lumagel scintillation cocktail (Baker). All samples were radioassayed in a Packard TriCarb liquid scintillation counter. Quench correction was performed by automatic external standardisation.

\section{RESULTS}

The sampled ice floe at Stn 140 was characterised by annual level sea ice of $93 \mathrm{~cm}$ thickness covered by snow $(13 \mathrm{~cm})$. The bottom $5 \mathrm{~cm}$ of the ice floe had an in situ temperature of $-1.7^{\circ} \mathrm{C}$ and a corresponding brine salinity of 30.5 (Assur 1958). Dissolved silicon $\left(\mathrm{Si}(\mathrm{OH})_{4}\right)$, phosphate $\left(\mathrm{PO}_{4}\right)$ and ammonium $\left(\mathrm{NH}_{4}\right)$ concentrations in the brine were $25.4 \pm 19.7,38.2 \pm 32.0$ and $30.5 \pm 15.3 \mu \mathrm{mol} \mathrm{l}^{-1}$, respectively (Table 1 ). Nitrate $\left(\mathrm{NO}_{3}\right)$ and nitrite $\left(\mathrm{NO}_{2}\right)$ were considerably lower at $3.3 \pm 4.1$ and $1.5 \pm 1.3 \mu \mathrm{mol} \mathrm{l^{-1 }}$, respectively. Low $\mathrm{Si}(\mathrm{OH})_{4}$ :DIN (dissolved inorganic nitrogen) $(0.75)$ and DIN: $\mathrm{PO}_{4}(0.88)$ as well as $\mathrm{Si}(\mathrm{OH})_{4}: \mathrm{NO}_{3}$ (7.69) and $\mathrm{NO}_{3}: \mathrm{PO}_{4}(0.09)$ ratios were calculated for the bottom

Table 1. In situ ice variables (means $\pm \mathrm{SD}$ ) and ratios averaged over bottom $5 \mathrm{~cm}$ of sampled ice floe at Stn 140

\begin{tabular}{|c|c|}
\hline Variable & Value \\
\hline Temperature $\left({ }^{\circ} \mathrm{C}\right)$ & $-1.7 \pm 0.0$ \\
\hline Brine content (\%) & $11.5 \pm 0.8$ \\
\hline Brine salinity & $30.5 \pm 0.0$ \\
\hline $\mathrm{NH}_{4}\left(\mu \mathrm{mol} \mathrm{l} \mathrm{l}^{-1}\right)$ & $30.5 \pm 15.3$ \\
\hline $\mathrm{NO}_{3}\left(\mu \mathrm{mol} \mathrm{l} \mathrm{l}^{-1}\right)$ & $3.3 \pm 4.1$ \\
\hline $\mathrm{NO}_{2}\left(\mu \mathrm{mol} \mathrm{l} \mathrm{l}^{-1}\right)$ & $1.5 \pm 1.3$ \\
\hline $\mathrm{PO}_{4}\left(\mu \mathrm{mol} \mathrm{l} \mathrm{l}^{-1}\right)$ & $38.2 \pm 32.0$ \\
\hline $\mathrm{Si}(\mathrm{OH})_{4}\left(\mu \mathrm{mol} \mathrm{l} \mathrm{l}^{-1}\right)$ & $25.4 \pm 19.7$ \\
\hline $\mathrm{Si}(\mathrm{OH})_{4}: \mathrm{NO}_{3}$ & 7.69 \\
\hline $\mathrm{NO}_{3:} \mathrm{PO}_{4}$ & 0.09 \\
\hline $\mathrm{Si}(\mathrm{OH})_{4}: \mathrm{DIN}$ & 0.75 \\
\hline DIN:PO $\mathrm{PO}_{4}$ & 0.88 \\
\hline Chl a ( $\mu \mathrm{g} \mathrm{l} \mathrm{l}^{-1}$ ice $)$ & $283.2 \pm 496.8$ \\
\hline Chl a ( $\mu \mathrm{g} \mathrm{l}^{-1}$ brine) & $2159.4 \pm 3582.2$ \\
\hline Chl a $\left(\mathrm{mg} \mathrm{m}^{-2}\right)$ & 8.5 \\
\hline Phaeo:chl a $\left(\mu \mathrm{g} \mathrm{l}^{-1}\right)$ & $0.2 \pm 0.1$ \\
\hline POC:PON $\left(\mu \mathrm{g} \mathrm{l}^{-1}\right)$ & $15.3 \pm 6.8$ \\
\hline
\end{tabular}



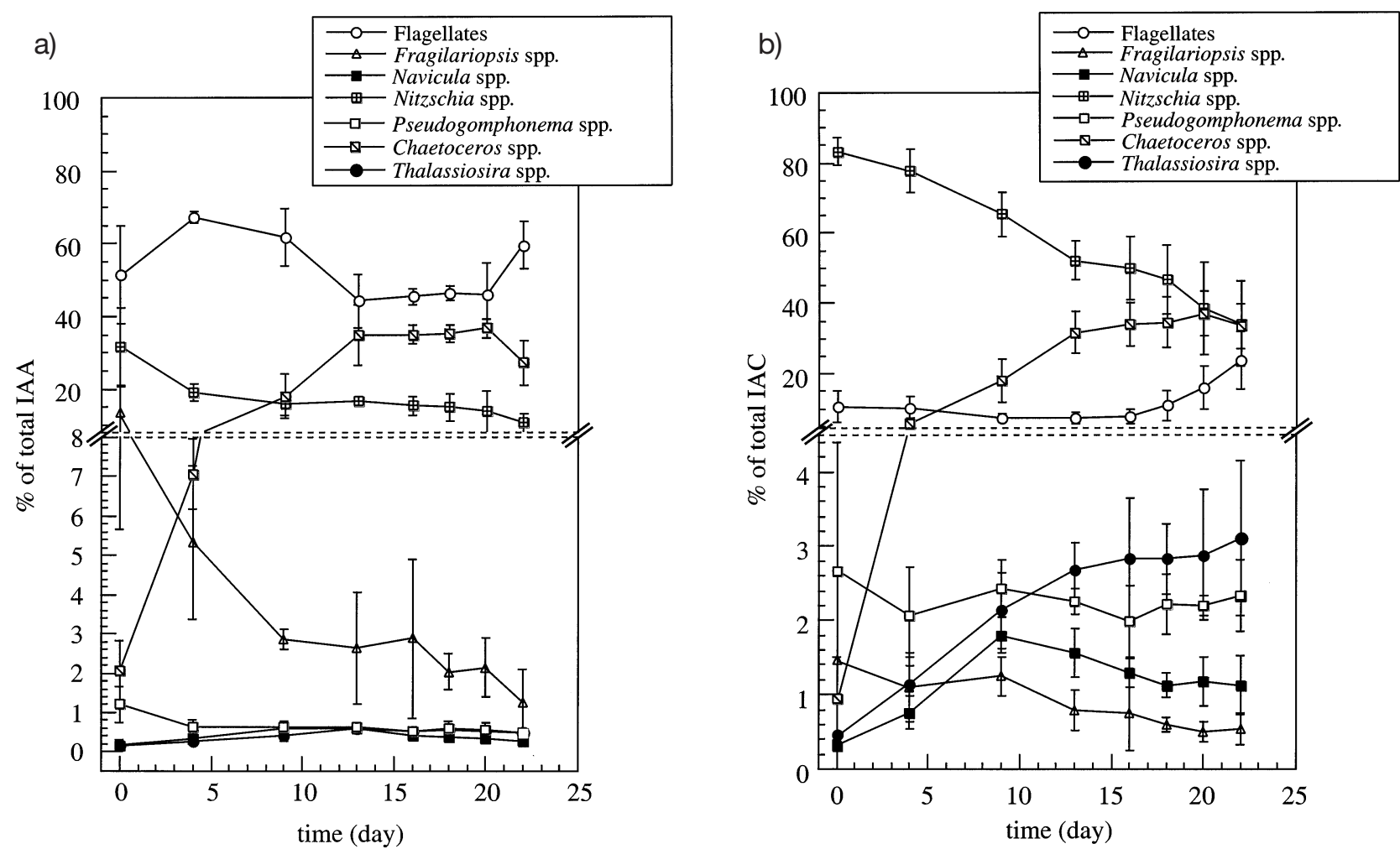

Fig. 1. Temporal development of ice-algae taxa in relative proportions of total ice-algae abundance, IAA (a), and of total ice-algae carbon, IAC (b). Error bars $= \pm \mathrm{SD}$

$5 \mathrm{~cm}$ of sea ice. Organic matter in the bottom $5 \mathrm{~cm}$ had a POC:PON ratio of $15.3 \pm 6.8$ and a phaeo:chl a ratio of $0.2 \pm 0.1$, with integrated chl a concentrations of $8.5 \mathrm{mg}$ $\mathrm{m}^{-2}$ (Table 1).

Six different genera of diatoms were distinguished within the bottom-ice community. The most abundant diatom taxon was Nitzschia spp. with the species $N$. frigida most dominant. This taxon contributed $31.6 \pm$ $10.9 \%$ to the total ice-algae abundance, IAA (Fig. 1a) and was followed by the genus Fragilariopsis spp. (13.3 $\pm 7.7 \%)$ and Chaetoceros spp. $(2.1 \pm 0.8 \%)$. The diatom genera Thalassiosira spp., Navicula spp. and Pseudogomphonema spp. each contributed $<1 \%$ to total IAA. Heterotrophic and autotrophic nanoflagellates including unidentified taxa, together with species belonging to chrysophytes, dinophytes and prasinophytes, clearly dominated the ice-algae community with $51.5 \pm 13.3 \%$ of total IAA.

On the basis of total ice-algae carbon (IAC), these flagellates comprised only $10.5 \pm 4.5 \%$, whereas Nitzschia spp. was the dominant genus with $83.2 \pm 4.0 \%$ of total IAC (Fig. 1b).

This ice-algae community grew to a final cell density of $9.0 \pm 1.5 \times 10^{4}$ cells ml $^{-1}$ within approximately $9 \mathrm{~d}$ at a rate of $0.22 \pm 0.03$ divisions $\mathrm{d}^{-1}$ (Table 2). The calculated chl a-specific growth rate was similar $\left(0.20 \pm 0.02 \mathrm{~d}^{-1}\right)$. The chl a concentrations increased from $7.1 \pm 0.4$ to $149.0 \pm 64.2 \mu \mathrm{g} \mathrm{l^{-1 }}$. Genus-specific growth rates of the dominant diatoms differed markedly. Chaetoceros spp. grew at rates of $0.49 \pm 0.06 \mathrm{~d}^{-1}$, Thalassiosira spp. and Navicula spp. at $0.38 \pm 0.11 \mathrm{~d}^{-1}$ and $0.39 \pm 0.02 \mathrm{~d}^{-1}$, respectively (Table 2 ). The 3 pennate diatoms Pseudogomphonema spp., Nitzschia spp. and Fragilariopsis spp. grew at only $0.19 \pm 0.05 \mathrm{~d}^{-1}, 0.16 \pm$ $0.02 \mathrm{~d}^{-1}, 0.09 \pm 0.04 \mathrm{~d}^{-1}$, respectively.

Table 2. Maximum $( \pm \mathrm{SD})$ growth rates $\left(\mathrm{d}^{-1}\right)$ under nutrientreplete conditions of different ice-algae taxa and bulk-parameters particulate organic carbon (POC), ice-algae carbon (IAC), chlorophyll a $(\mathrm{chl}$ a) and ice-algae abundance (IAA) during the first $9 \mathrm{~d}$ of experiment

\begin{tabular}{|lc|}
\hline Variable/genus & Max. growth rate $\left(\mathrm{d}^{-1}\right)$ \\
\hline POC & $0.15 \pm 0.02$ \\
IAC & $0.16 \pm 0.02$ \\
Chl a & $0.20 \pm 0.02$ \\
IAA & $0.22 \pm 0.03$ \\
Fragilariopsis spp. & $0.09 \pm 0.04$ \\
Navicula spp. & $0.39 \pm 0.02$ \\
Nitzschia spp. & $0.16 \pm 0.02$ \\
Pseudogomphonema spp. & $0.19 \pm 0.05$ \\
Chaetoceros spp. & $0.49 \pm 0.06$ \\
Thalassiosira spp. & $0.38 \pm 0.11$ \\
\hline
\end{tabular}




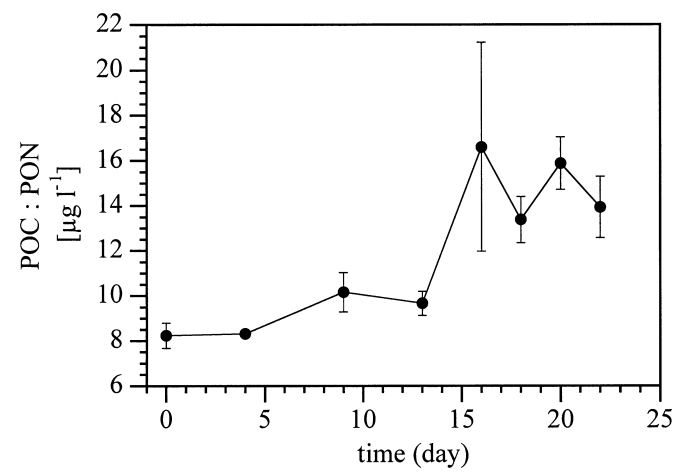

Fig. 2. Temporal development of the particulate organic carbon (POC):nitrogen $(\mathrm{PON})$ ratios. Error bars $= \pm \mathrm{SD}$

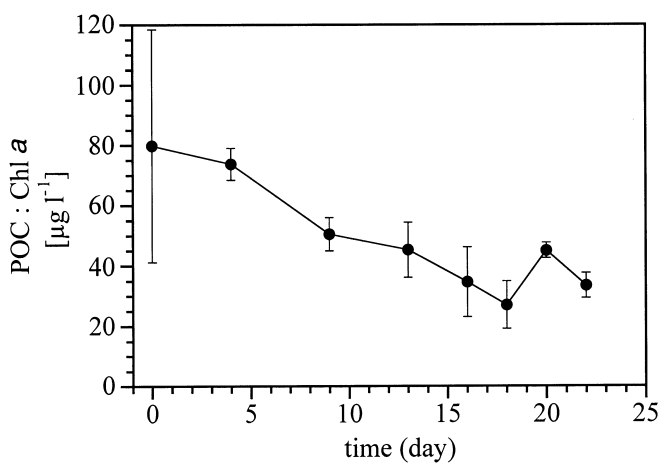

Fig. 3. Temporal development of the particulate organic carbon (POC) chlorophyll $a(\mathrm{chl} a)$ ratios. Error bars $= \pm \mathrm{SD}$

These different growth rates resulted in a species succession during the experiment (Fig. 1a). The relative proportion of Chaetoceros spp. increased from initially $2.1 \pm 0.8 \%$ to a maximum of $36.6 \pm 2.7 \%$ of total IAA at Day 20. Decreasing proportions were observed for Nitzschia spp. and Fragilariopsis spp. from initially $31.6 \pm 10.9$ to $10.7 \pm 2.6 \%$ and $13.3 \pm 7.7$ to $1.3 \pm 0.8 \%$, respectively. The contribution of the remaining diatom genera as well as that of flagellates varied insignificantly. Similar shifts in the relative proportions were

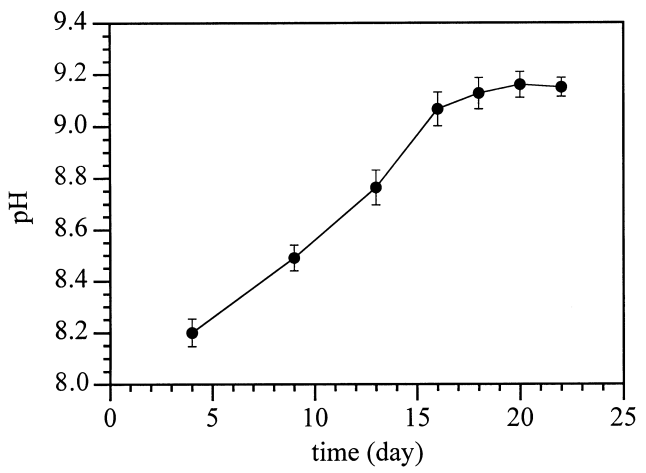

Fig. 4. Temporal development of $\mathrm{pH}$. Error bars $= \pm \mathrm{SD}$
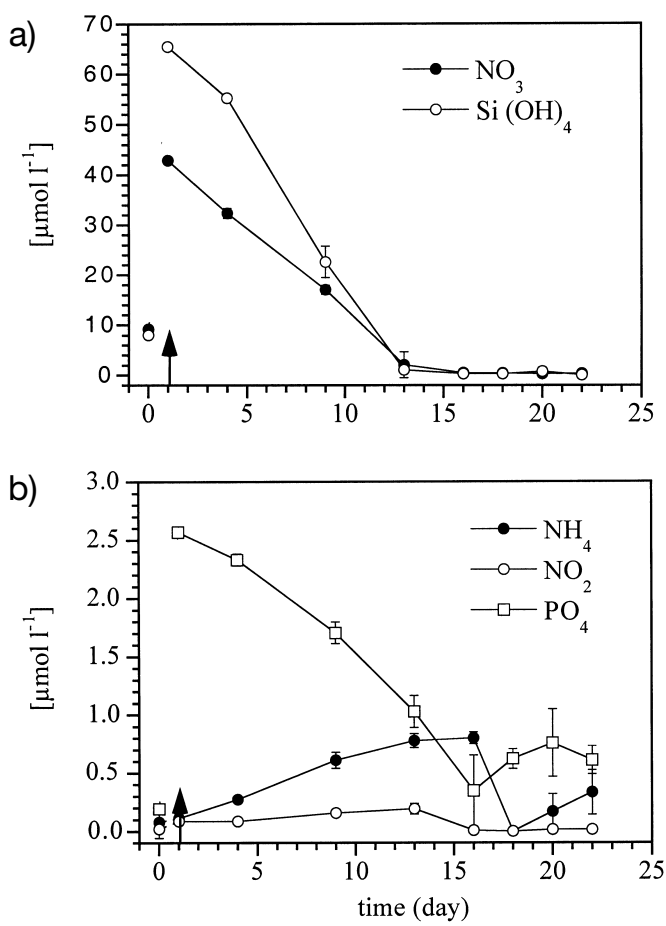

Fig. 5. Temporal development of (a) dissolved silicon and nitrate and (b) phosphate, ammonium and nitrite. Arrows indicate day of nutrient inoculation. Error bars $= \pm \mathrm{SD}$

found on the basis of IAC (Fig. 1b). Despite these successional changes each taxon grew exponentially until only Day 9.

Most POC:PON ratios of the ice algal cultures were below 10 until Day 13, and increased thereafter to ca 15 (Fig. 2). POC:chl a ratios of the algal community decreased gradually during growth (Fig. 3). The $\mathrm{pH}$ increased from initially $8.20 \pm 0.05$ to $9.15 \pm 0.04$ (Fig. 4). The nutrients $\mathrm{Si}(\mathrm{OH})_{4}$ and $\mathrm{NO}_{3}$ had initial concentrations of $65.5 \pm 0.36$ and $42.9 \pm 0.61 \mu \mathrm{mol} \mathrm{l^{-1 }}$, respectively at Day 1 after addition of the nutrients (Fig. 5a). After Day 13, they were depleted to concentrations below $1 \mu \mathrm{mol} \mathrm{l^{-1 }}$. Phosphate concentrations of initially $2.57 \pm 0.04 \mu \mathrm{mol} \mathrm{l}^{-1}$ decreased during ice algal growth, but not below concentrations which were measured before nutrient addition, except for Culture 3 (Fig. 5b). Nitrite and ammonium concentrations increased until Day $13\left(0.2 \pm 0.04 \mu \mathrm{mol} \mathrm{l}^{-1} \mathrm{NO}_{2}\right)$ and Day $16\left(0.8 \pm 0.05 \mu \mathrm{mol} \mathrm{l}^{-1} \mathrm{NH}_{4}\right)$. Later, both nutrients were rapidly depleted, except for ammonium which increased again (Fig. 5b).

$\mathrm{Si}(\mathrm{OH})_{4}: \mathrm{NO}_{3}$ as well as the $\mathrm{NO}_{3}: \mathrm{PO}_{4}$ ratios decreased continuously with time until $\mathrm{NO}_{3}$ and $\mathrm{Si}(\mathrm{OH})_{4}$ were depleted at Day 16 (Fig. 6). Thereafter, the $\mathrm{Si}(\mathrm{OH})_{4}$ : $\mathrm{NO}_{3}$ ratios increased to intermediate peak values during the stationary algal growth period, whereas the $\mathrm{NO}_{3}: \mathrm{PO}_{4}$ ratios remained at a low level (Fig. 6). 

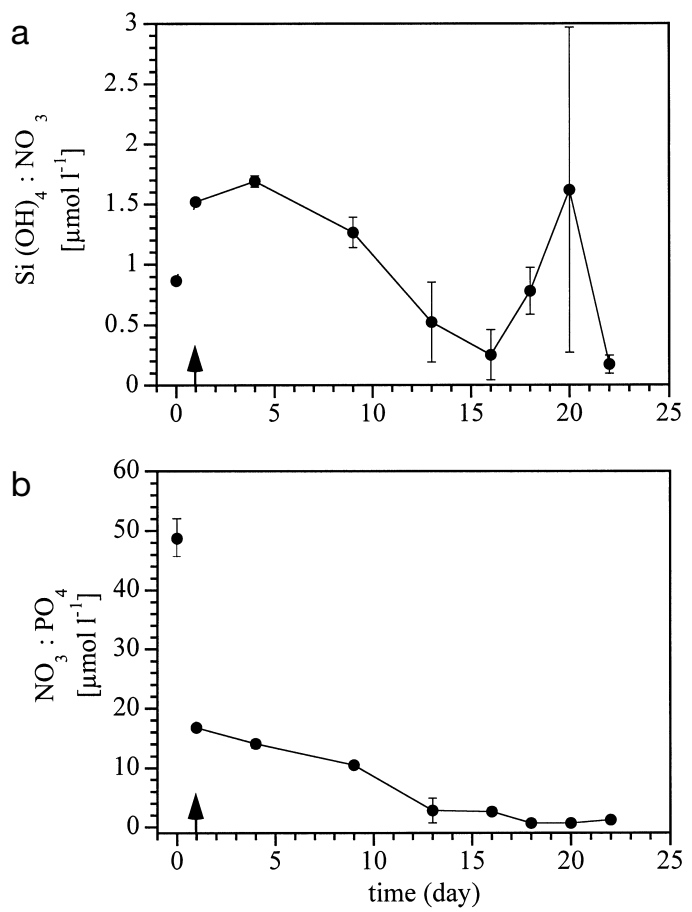

Fig. 6. Temporal development of $\mathrm{Si}(\mathrm{OH})_{4}: \mathrm{NO}_{3}$ (a) and $\mathrm{NO}_{3}: \mathrm{PO}_{4}$ (b) ratios. Arrows indicate day of nutrient inoculation. Error bars $= \pm \mathrm{SD}$

Chl a-specific production $\left(\mathrm{P}^{\mathrm{chl} a}\right)$ ratios increased from an initial $0.17 \pm 0.11$ to $0.68 \pm 0.05 \mu \mathrm{g} \mathrm{C} \mu \mathrm{g} \mathrm{chl} a^{-1}$ $\mathrm{h}^{-1}$ between Days 10 and 15 at the end of the growth period (Fig. 7). Exudation rates of the ice algal community increased during the log growth phase to maximal values of $7.0 \pm 1.1 \%$ of the total production (Fig. 8). Exudation rates were reduced under nutrient depletion.

Nutrient addition caused a rapid change in the pathways of photosynthetic carbon assimilation (Fig. 9). Predominant macromolecular classes before nutrient inoculation were lipids $(54.6 \pm 0.4 \%$ of total particulate production) and LMWM $(35.0 \pm 1.0 \%)$, with lower allo-

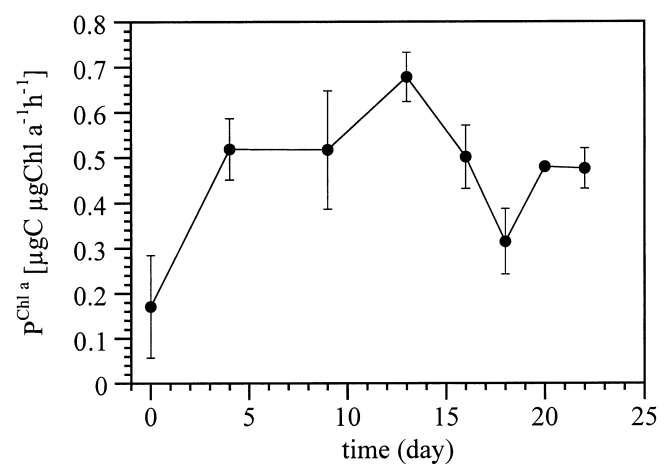

Fig. 7. Temporal development of chlorophyll a (chl a) specific primary production $\mathrm{P}^{\text {chl a }}\left(\mu \mathrm{g} \mathrm{C} \mu \mathrm{g} \mathrm{chl} a^{-1} \mathrm{~h}^{-1}\right)$. Error bars $= \pm \mathrm{SD}$

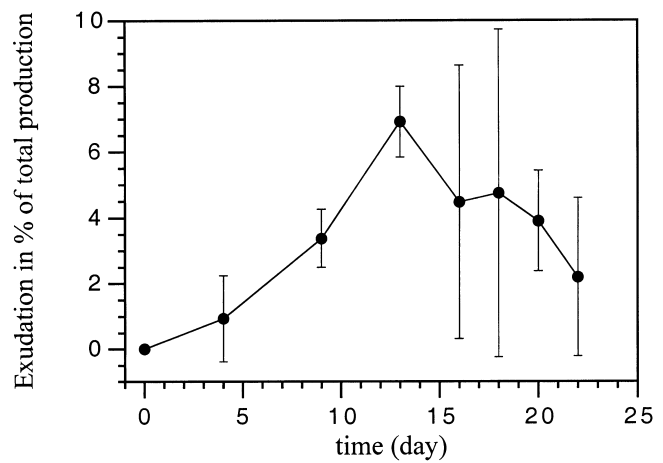

Fig. 8. Temporal development of exudation (\% of total production). Error bars $= \pm \mathrm{SD}$

cation to proteins $(3.0 \pm 0.8 \%)$ and polysaccharides $(7.3 \pm 0.1 \%)$. After the first $3 \mathrm{~d}$, a significant decrease of lipids was observed, whereas the proportion of proteins increased rapidly to $14.8 \pm 6.3 \%$ of total particulate production. A moderate increase to $45.7 \pm 6.3 \%$ was observed for the LMWM. During the subsequent days of logarithmic growth (until Day 10), the absolute and relative production of proteins again decreased, whereas the production of carbohydrates increased further. The production of the remaining assimilatory products, lipids and LMWM, was more or less constant over the log growth phase of the algae. The transition from logarithmic to stationary growth after Day 10 had strong implications for allocation of carbon among photosynthetic end products. Carbohydrates attained the maximal relative proportion with $12.9 \pm 1.3 \%$ of the total particulate production (Fig. 9a). At the same time, a rapid increase of lipid formation from $32.0 \pm$ $0.4 \%$ to $71.0 \pm 3.6 \%$ was observed. Especially glycolipids $(56.2 \pm 0.1 \%$ to $82.0 \pm 1.1 \%$ of total particulate lipid production) were responsible for the rapid increase of lipid formation (Fig. 9b). Later, production of LMWM decreased to $23.5 \pm 1.0 \%$ ). Proteins and carbohydrates also attained their lowest production rates. The most important assimilation pathway for ice algae under nutrient limitation remained the lipid pathway. The lipids of the ice algae were clearly dominated by glycolipids, whereas the phospholipid fraction simultaneously decreased. However, the neutral lipid production was obviously not influenced by changes of icealgae growth in nutrient status.

\section{DISCUSSION}

In May, the conditions in the annual sea-ice cover of the Barents Sea are typically characterised by the onset of melting (Hegseth 1992), which during our study was also indicated by a relatively low brine salinity (30.5) in the bottom $5 \mathrm{~cm}$ of the sea ice and a corre- 
a

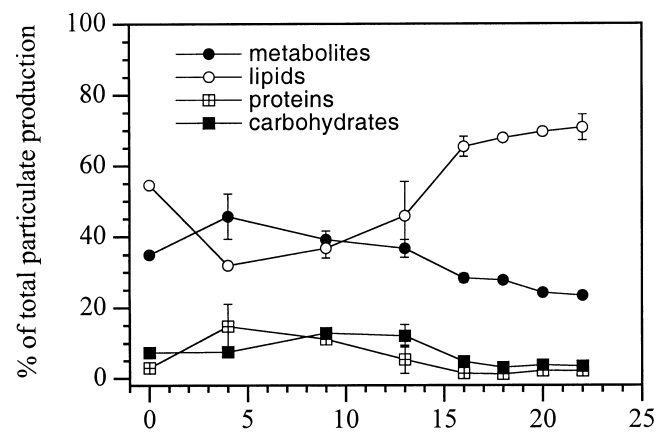

$\mathrm{b}$

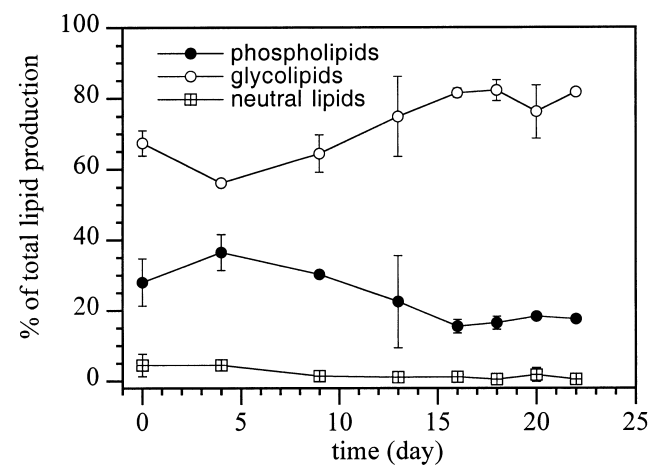

Fig. 9. Temporal changes in contribution of (a) photosynthetic end products to total particulate production (\%) and of (b) lipid classes to total particulate lipid production (\%). Error bars $= \pm \mathrm{SD}$

sponding ice temperature of $-1.7^{\circ} \mathrm{C}$ (Table 1 ). Salinity in Arctic surface water of ice-covered regions of the Barents Sea in May ranges between 34.4 and 34.6 (Hegseth 1992). The salinity difference between brine within the bottom sea ice and sea water in the springearly summer transition results in a perceptible stratification within the ice-water interface (e.g., Allen 1971, Legendre et al. 1981). The relatively high ammonium concentrations $\left(30.5 \pm 15.5 \mu \mathrm{mol} \mathrm{l^{-1 }}\right)$ compared to the nitrate concentrations $\left(3.3 \pm 4.1 \mu \mathrm{mol} \mathrm{l}^{-1}\right)$ can be attributed to heterotrophic activity (Meguro et al. 1967, Alexander et al. 1974, Sullivan \& Palmisano 1981) and a restricted supply of new nutrients such as nitrate due to the density stratification (Legendre et al. 1981, Gosselin et al. 1985). The large standard deviations of nutrient concentrations (Table 1) were caused by strong gradients, with maximum concentrations of all nutrients within the bottom $1 \mathrm{~cm}$ of sea ice. This commonly observed nutrient distribution (Smith et al. 1990, Mock \& Gradinger 1999) within Arctic sea ice is either related to gravity drainage of colder and therefore denser brine solutions from above (Meguro et al. 1967, Maykut 1985), inflow of nutrient-rich water from the surface sea water, or the nutrient pools within ice algae (Cota et al. 1987, 1990, Cota \& Horne 1989). The latter hypothesis is supported by maximum chl a concentrations $\left(283.2 \pm 496.8 \mathrm{\mu g} \mathrm{l}^{-1}\right)$ within the bottom $5 \mathrm{~cm}$ of sea ice (Table 1). Nutrient assimilation, a relatively low regeneration potential of the internal communities, together with gravity drainage of brine are reasons for decreasing concentrations toward the ice surface. Dissolved silicon (4.9 to $5.8 \mathrm{\mu mol} \mathrm{l}^{-1}$ ), nitrate (9.6 to $10.5 \mu \mathrm{mol} \mathrm{l}^{-1}$ ) and phosphate ( 0.65 to $0.96 \mu \mathrm{mol} \mathrm{l}^{-1}$ ) concentrations within surface waters (0 to $1 \mathrm{~m}$ ) of the Barents Sea during May (Hegseth 1992) are considerably lower than those in sea-ice brine. However, the $\mathrm{Si}(\mathrm{OH})_{4}: \mathrm{NO}_{3}$ ratio of surface water $(0.53$ : Hegseth 1992) was not comparable to the brine values (7.69), but did correspond to the $\mathrm{Si}(\mathrm{OH})_{4}$ :DIN ratio $(0.75)$ of brine. The high phosphate concentration of brine was responsible for an $\mathrm{NO}_{3:} \mathrm{PO}_{4}$ ratio of 0.09 , whereas sea water typically has a far higher ratio of 13.5 (Hegseth 1992).

After nutrient addition in our experiment, the ratio of $\mathrm{Si}(\mathrm{OH})_{4}: \mathrm{NO}_{3}(1.5)$ was in the range of natural brine and sea water (see above), while the $\mathrm{NO}_{3}: \mathrm{PO}_{4}$ ratio of 18 is comparable only to the sea water values of the Barents Sea because of the extremely high phosphate concentrations in the sea ice. The initial absolute nutrient concentrations of the 3 batch cultures were similar to in situ brine concentrations within the bottom $5 \mathrm{~cm}$ at Stn 140, but were higher than sea water values. A similar relation between in situ conditions and the experimental set-up was attained for irradiance. Under-ice irradiance was measured beneath first-year level sea ice on the cruise. Unfortunately no direct irradiance measurements for Stn 140 are available because of a defect sensor.

The taxonomic composition of the ice-algae community in the 3 treatments was similar, which indicates a homogeneous organism distribution at this station. A comparison with other spring investigations (Hegseth 1992, Falk-Petersen et al. 1998, Henderson et al. 1998) clearly shows that the algal community is representative for the spring community of the sea-ice ecosystem in this region.

The exponential growth of the algal community during the experiment was triggered primarily by the addition of sufficient nutrients. The growth rates of the algal communities and the genus-specific growth rates were generally similar to observations in other Arctic and Antarctic ice-algae studies (Maestrini et al. 1986, Grossi et al. 1987, Cota \& Sullivan 1990, Gilstad \& Sakshaug 1990, Johnson \& Hegseth 1991, Hegseth 1992, Kirst \& Wiencke 1995), and agree exceptionally well with growth rates recorded during field studies in the Barents Sea (Hegseth 1992). Nonetheless, different growth rates of the diatom genera lead to a species succession with time. The dominance of Nitzschia spp. in the diatom community on the basis of IAA and IAC at the beginning of the experiment was replaced by Chaetoceros spp. and autotrophic flagellates during 
the growth period. The chrysophytes became more important during the end of the experiment (data not shown). This may have several reasons: the first is related to the species-specific nutrient requirement. Each algal species has unique nutrient affinities (Sommer 1986, 1991) which lead to species-specific growth kinetics. Possibly the high dissolved silicon concentration in the cultures allowed for rapid growth of Chaetoceros spp., a genus with a higher $\mathrm{Si}(\mathrm{OH})_{4}$ demand because of their silicon spines. The dominant ice-algae genus Nitzschia spp. could be better acclimated to lower nutrient concentrations within the ice, especially for dissolved silicon. The decreasing $\mathrm{Si}(\mathrm{OH})_{4}: \mathrm{NO}_{3}$ and $\mathrm{NO}_{3}: \mathrm{PO}_{4}$ ratios during the exponential growth of the algae indicate a generally higher demand for dissolved silicon and phosphate than for nitrate. The silicate and phosphate concentrations in the brine channels were far below common half-saturation constants for growth (Sommer 1986, 1991), and may thus have caused nutrient-limited growth together with faster uptake of dissolved silicon than nitrate in the batch cultures.

However, in the same manner that the different nutrient affinities can cause species succession, active pathways of inorganic carbon acquisition may constitute an important factor driving algal species succession, especially within the brine-channel habitat of sea ice (Gleitz et al. 1996). During decreasing $\mathrm{CO}_{2}$ concentration, indicated by increasing $\mathrm{pH}$ values in the cultures, the photosynthetic carbon demand may exceed diffusional $\mathrm{CO}_{2}$ supply, especially for larger algae. From these considerations, smaller algae like Chaetoceros spp. may have been more successful than larger species of the genera Nitzschia or Thalassiosira. Gleitz et al. (1996) observed in an Antarctic sea-ice diatom (Chaetoceros cf. neogracile), the physiological ability to actively assimilate $\mathrm{HCO}_{3}{ }^{-}$at $\mathrm{CO}_{2}$ (aq) concentrations $<0.5 \mu \mathrm{M}$ and $\mathrm{pH}>9.5$. The $\mathrm{pH}$ in our experiment never exceeded 9.2; thus, the diffusional $\mathrm{CO}_{2}$ (aq) flux should be sufficient to satisfy cellular carbon demand, except for larger diatoms which occur only in insignificant concentrations.

Another explanation for the observed species succession is related to grazing pressure by microheterotrophs such as ciliates or nanoflagellates. Both groups were seen in low numbers. Unfortunately the abundances of these groups were not quantified, but they could have been responsible for the rapid decrease in the relative proportions of Fragilariopsis spp. and Nitzschia spp.

The sea-ice algae community grew exponentially until Day 9, but the chl a-specific production rate $\left(\mathrm{P}^{\text {chl }}{ }^{a}\right)$ attained maximum values at Day 13 , as did the exudation rates of dissolved organic carbon. Consequently, from Days 9 until 13, an uncoupling between organic carbon synthesis and growth occurred which also explains the increasing $\mathrm{C}: \mathrm{N}$ ratios of the algae. No enhanced exudation was observed after nutrient depletion. Between 0 and $10 \%$ exudation of total particulate production is within the range reported for polar and temperate phytoplankton as well as for ice algae (Williams \& Yentsch 1976, Smith et al. 1977, Larsson \& Hagström 1982, Palmisano \& Sullivan 1985).

The relative contribution of photosynthetic endproducts to total particulate production summarizes the temporal development for each assimilate. Under sufficient nutrient supply the dominant pathway was the production of LMWMs, which are the precursors of macromolecules such as free amino acids and carbohydrates (Smith et al. 1989, Tillmann et al. 1989, Lindquist \& Lignell 1997). Storage of free amino acids in diatom cells was already described by Conover (1975) and Dortch et al. (1984), storage of carbohydrates by Antia et al. (1963), Handa (1969), Haug \& Myklestad (1976) and Lancelot \& Mathot (1985). The determination of carbohydrates as metabolites or within the polysaccharide fraction depends on the structure, grade of polymerisation, and solubility of these substances (Hitchcock 1983, Tillmann et al. 1989).

A rapid conversion of amino acids into proteins was indicated by the increase of protein production during the first $4 \mathrm{~d}$ after nutrient inoculation. Despite sufficient nitrate concentrations until Day 13, the protein production decreased after Day 4 and nearly completely ceased under nitrate depletion. Carbohydrate production also increased during the exponential growth phase, but attained the maximal values after the protein peak between Days 8 and 13. The production of LMWM was more or less constant between Days 4 and 13. According to Morris et al. (1974), changes in the protein synthesis rate are accompanied by changes in the metabolite or polysaccharide fraction. LMWM accounted for $40 \%$ of the total particulate production under exponential growth, whereas both proteins as well as carbohydrates never exceeded $20 \%$ of the total particulate production. Identical allocation patterns by Arctic-ice algae of LMWM (36.3 to $42.9 \%$ ), proteins (19.3 to $23.1 \%$ ) and polysaccharides (16.5 to $21.8 \%$ ) were found during the entire spring growth season under similar photon-flux densities (PFDs) of 3.5 to $33.0 \mu \mathrm{mol}$ photons $\mathrm{m}^{-2} \mathrm{~s}^{-1}$ by Smith et al. (1989). However, Smith et al. (1997), in a comparable experiment with spring sea-ice algae communities, found high allocation into proteins during the exponential growth of sea-ice algae (62 to $66 \%$ ) and only a moderate decreasing allocation under stationary growth (48 to $49 \%$ ). One reason for the dominance of protein allocation in their experiments could be related to an incomplete nitrogen depletion, which is indicated 
by their final nitrate/nitrite and ammonium concentrations. Another explanation could be the light intensity under which the algae were grown. The experiments of Smith et al. (1997) were done under $20 \mu \mathrm{mol}$ photons $\mathrm{m}^{-2} \mathrm{~s}^{-1}$, with initial POC:chl a ratios of ca 8 and final ratios of ca 140 . Consequently, the algae initially grew under low light conditions and then with decreasing chl a concentrations per carbon unit, which is typical for high-light acclimation and chl a decomposition, respectively. Our experiments were initially done under an average of $15 \mu \mathrm{mol}$ photons $\mathrm{m}^{-2} \mathrm{~s}^{-1}$, with POC:chl a ratios of ca 80 and finally of ca 25 , which contrasted with Smith et al. conditions. This process led to an enhanced chl a production with a corresponding nitrogen demand for synthesis of the terapyrrol-ring of chl a (Larson \& Rees 1996). Therefore, low carbon allocation into proteins after Day 4 could be explained by higher pigment synthesis under lowlight conditions. In addition to the effects of low-light acclimation on pigment synthesis, the thylakoid membrane as well as the size of the chloroplasts also increased. The algae need structural lipids such as glycolipids, e.g. monogalactotosyl- and digalactosyldiacylglycerols for this morphological change. These are dominant lipid classes of the thylakoidmembrane (e.g. Siegenthahler et al. 1987) as well as outer and inner chloroplast membranes (Douce et al. 1984, Mendida-Morgenthaler et al. 1985). Glycolipids were intensively produced after Day 4, when LMWM as well as proteins decreased. They constituted up to $80 \%$ of the total particulate lipid production under nutrient exhaustion between Days 13 and 22. Under stationary algal growth after Day 16, the POC:chl a ratio remained more or less constant because of missing dissolved nitrogen.

Our results clearly indicate that the availability of nutrients, especially dissolved nitrogen under lowlight acclimation, significantly influences the pathway of carbon in the cell. Sufficient nutrient concentrations and irradiance caused an increase in production of LMWM and proteins. During decreasing nutrient concentrations and irradiance, the lipid pathway has priority. However, pigments and glycolipids, which are important components of chloroplasts, increase with decreasing nutrient concentration and irradiance and not the neutral lipids.

Acknowledgements. We are grateful to Eva-Maria Nöthig and Urban Tillmann for valuable discussions and to the crew of the RV 'Polarstern' for their assistance during the expedition. We thank our colleagues G. Donner, F. Haass, K. Meiners and Q. Zhang who helped us during the field work. M. Krumbholz kindly assisted us with the POC samples, A. Lunau determined the nutrients. Gerhard Dieckmann is thanked for reviewing an earlier version of the manuscript, and making suggestions for its improvement.

\section{LITERATURE CITED}

Alexander V, Horner R, Clasby CR (1974) Metabolism of Arctic sea ice organisms. Institute of Marine Science, University of Alaska, Fairbanks (Rep R74-4)

Allen MB (1971) High-latitude phytoplankton. Annu Rev Ecol Syst 2:261-276

Antia J, McAllister CD, Parsons TR, Stephens S, Strickland JDH (1963) Further measurement of primary production using a large-volume plastic sphere. Limnol Oceanogr 8: 166-183

Arar EJ, Collins GB (1992) In vitro determination of chlorophyll $a$ and phaeophytin $a$ in marine and freshwater phytoplankton by fluorescence. Method 445.0. In: USEPA, Methods for the determination of chemical substances in marine and estuarine environmental samples. Environmental Protection Agency (EPA), Cincinnati, OH

Arrigo KR, Worthen DL, Lizotte MP, Dixon P, Dieckmann G (1997) Primary production in Antarctic sea ice. Science 276:394-397

Assur A (1958) Composition of sea ice and its tensile strength. Publs Natl Res Coun Wash 589:106-138

Baltic Marine Environment Protection Commission (1988) Guidelines for the Baltic Monitoring Programm for the third stage. Part D. Biological determinants. Proceedings of the Baltic Sea Environment No. 27 D. Helsinki Commission, Helsinki

Bartsch A (1989) Die Eisalgenflora des Weddellmeeres (Antarktis): Artenzusammensetzung und Biomasse sowie Ökophysiologie ausgewählter Arten. Ber Polarforsch 63: $1-110$

Bates SS, Cota GF (1986) Fluorescence induction and photosynthetic responses of Arctic ice algae to sample treatment and salinity. J Phycol 22:421-429

Bunt JS (1968) Some characteristics of microalgae isolated from Antarctic sea ice. Antarct Res Ser 11:1-14

Conover SAM (1975) Partitioning of nitrogen and carbon in cultures of the marine diatom Thalassiosira fluviatilis supplied with nitrate, ammonium or urea. Mar Biol 32: 231-246

Cota GF (1985) Photoadaptation of high Arctic ice algae. Nature 315:219-222

Cota GF, Horne EP (1989) Physical control of arctic ice algal production. Mar Ecol Prog Ser 52:111-121

Cota GF, Smith REH (1991) Ecology of bottom ice algae. III. Comparative physiology. J Mar Syst 2:297-315

Cota GF, Sullivan CW (1990) Photoadaptation, growth and production of bottom ice algae in the Antarctic. J Phycol 26:399-411

Cota GF, Prinsenberg SJ, Bennett EB, Loder JW, Lewis MR, Anning JL, Watson NHF, Harris LR (1987) Nutrient fluxes during extended blooms of Arctic ice algae. J Geophys Res 92:1951-1962

Cota GF, Anning JL, Harris LR, Harrison WG, Smith REH (1990) Impact of ice algae on inorganic nutrients in seawater and sea ice in Barrow Strait, NWT, Canada, during spring. Can J Fish Aquat Sci 47:1402-1415

Crawford RM, Gardner C, Medlin LK (1994) The genus Attheya. I. A description of four new taxa, and the transfer of Gonioceros septentrionalis and G. armatas. Diatom Res $9(1): 27-51$

Demers S, Legendre L, Maestrini SY, Rochet M, Ingram RG (1989) Nitrogenous nutrition of sea-ice microalgae. Polar Biol 9:377-383

Dortch Q, Clayton JR Jr, Thoresen SS, Ahmed SI (1984) Species differences in accumulation of nitrogen pools in phytoplankton. Mar Biol 81:237-250 
Douce R, Block MA, Dorne AJ, Joyard J (1984) The plastid envelope membranes: their structure, composition and role in chloroplast biogenesis. Subcell Biochem 10:1-84

Falk-Petersen S, Sargent JR, Henderson J, Hegseth EN, Hop H, Okolodkov YB (1998) Lipids and fatty acids in ice algae and phytoplankton from the marginal ice zone in the Barents Sea. Polar Biol 20:41-47

Fiala M, Oriol L (1990) Light-temperature interactions on the growth of Antarctic diatoms. Polar Biol 10:629-636

Fogg GE (1959) Nitrogen nutrition and metabolic patterns in algae. Symp Soc Exp Biol 13:106-125

Garrison DL, Buck KR (1986) Organism losses during ice melting: a serious bias in sea ice community studies. Polar Biol 6:237-239

Gilstad M, Sakshaug E (1990) Growth rates of ten diatom species from the Barents Sea at different irradiances and day lengths. Mar Ecol Prog Ser 64:169-173

Gleitz M, Kirst GO (1991) Photosynthesis-irradiance relationship and carbon metabolism of different ice algal assemblages collected from Weddell Sea pack ice during austral spring (EPOS 1). Polar Biol 11:385-392

Gleitz M, Vonderloeff MR, Thomas DN, Dieckmann GS, Millero FJ (1995) Comparison of summer and winter inorganic carbon, oxygen and nutrient concentrations in Antarctic sea ice brine. Mar Chem 51:81-91

Gleitz M, Kukert H, Riebesell U, Dieckmann GS (1996) Carbon acquisition and growth of Antarctic sea ice diatoms in closed bottle incubations. Mar Ecol Prog Ser 135:169-177

Gosselin M, Legendre L, Demers S, Ingram RG (1985) Responses of sea-ice microalgae to climatic and fortnightly tidal energy inputs (Manitounuk Sound, Hudson Bay). Can J Fish Aquat Sci 42:999-1006

Gosselin M, Levasseur M, Wheeler PA, Horner RA, Booth BC (1997) New measurements of phytoplankton and ice algal production in the Arctic ocean. Deep-Sea Res 44: 1623-1644

Gran HH (1904) Diatomaceae from the ice-floes and plankton of the Arctic Ocean. Sci Res Norw N Polar Exped 11:1-74

Grasshoff K, Ehrhard M, Kremling K (1983) Methods of seawater analyses, 2nd edn. Verlag Chemie, Weinheim

Grossi SMcG, Kottmeier ST, Moe RL, Taylor GT, Sullivan CW (1987) Sea ice microbial communities. VI. Growth and primary production in bottom ice under graded snow cover. Mar Ecol Prog Ser 35:153-164

Guckert JB, Antworth CP, Nichols PD, White DC (1985) Phospholipid, ester-linked fatty acid profiles as reproducible assays for changes in prokaryotic community structure of estuarine sediments. FEMS Microbiol Ecol 31:147-158

Handa N (1969) Carbohydrate metabolism in the marine diatom Skeletonema costatum. Mar Biol 4:208-214

Harwood JL, Jones AL (1989) Lipid metabolism in algae. Adv Bot Res 16:1-53

Haug A, Myklestad S (1976) Polysaccharides of marine diatoms with specual reference to Chaetoceros species. Mar Biol 34:217-222

Hegseth EN (1992) Sub-ice algal assemblages of the Barents Sea: species composition, chemical composition, and growth rates. Polar Biol 12:485-496

Henderson RJ, Hegseth EN Park MT (1998) Seasonal variation in lipid and fatty acid composition of ice algae from the Barents Sea. Polar Biol 20:48-55

Hitchcock GL (1983) Photosynthate partitioning in cultured marine Phytoplankton. 1. Dinoflagellates. J Exp Mar Biol Ecol 69:21-36

Husted F (1966) Die Kieselalgen. Rabenhorsts Kryptogamenflora. Akademischer Verlag, Leipzig

Ikävalko J, Gradinger R (1997) Flagellates and heliozoans in the Greenland Sea ice studied alive using light microscopy. Polar Biol 17:473-481

Iwamoto H, Yonekawa G, Asia T (1955) Fat synthesis in unicellular algae. I. Culture conditions for fat accumulation in Chlorella cells. Bull Agric Chem Soc Jpn 19:240-252

Johnsen G, Hegseth EN (1991) Photoadaptation of sea ice microalgae in the Barents Sea. Polar Biol 11:179-184

Kirst GO, Wiencke C (1995) Ecophysiology of polar algae. J Phycol 31:181-199

Klyachko-Gurvich GL, Tsoglin LN, Doucha J, Kopetskii J, Ryabykh IBS, Semeneko VE (1999) Desaturation of fatty acids as an adaptive response to shifts in light intensity. Physiol Plant 107:240-249

Kottmeier ST, Sullivan CW (1988) Sea ice microbial communities (SIMCO). 9. Effects of temperature and salinity on rates of metabolism and growth of autotrophs and heterotrophs. Polar Biol 8:293-304

Lancelot C, Mathot S (1985) Biochemical fractionation of primary production by phytoplankton in Belgian coastal waters during short- and long-term incubations with ${ }^{14} \mathrm{C}$ bicarbonate. I. Mixed diatom population. Mar Biol 86: 219-226

Larson TR, Rees AV (1996) Changes in cell composition and lipid metabolism mediated by sodium and nitrogen availability in the marine diatom Phaeodactylum tricornutum (Bacillariophyceae). J Phycol 32:388-393

Larsson U, Hagström A (1982) Fractionated phytoplankton primary production, exudate release and bacterial production in a Baltic eutrophication gradient. Mar Biol 67: $57-70$

Legendre L, Ingram RG, Poulin M (1981) Physical control of phytoplankton under sea ice (Manitounuk Sound, Hudson Bay). Can J Fish Aquat Sci 38:1385-1392

Li WKW, Platt T (1982) Distribution of carbon among photosynthetic end-products in phytoplankton of the eastern Canadian Arctic. J Phycol 18:466-471

Li WKW, Glover HE, Morris I (1980) Physiology of carbon photoassimilation by Oscillatoria thiebautii in the Caribbean Sea. Limnol Oceanogr 25(3):447-456

Lindquist $\mathrm{K}$, Lignell $\mathrm{R}$ (1997) Intracellular partitioning of ${ }^{14} \mathrm{CO}_{2}$ in phytoplankton during a growth season in the northern Baltic. Mar Ecol Prog Ser 152:41-50

Maestrini SY, Rochet M, Legendre L, Demers S (1986) Nutrient limitation of the bottom-ice microalgae biomass (southern Hudson Bay, Canadian Arctic). Limnol Oceanogr 31:969-982

Maykut GA (1985) The ice environment. In: R Horner (ed) Sea ice biota. CRC Press, Boca Raton, p 21-82

Medlin LM, Priddle J (1990) Polar marine diatoms, 2nd edn. British Antarctic Survey, Cambridge

Meguro H, Ito K, Fukushima H (1967) Ice flora (bottom type): a mechanism of primary production in polar seas and the growth of diatoms in sea ice. Arctic 20:114-133

Mendida-Morgenthaler L, Eichenberger W, Boschetti A (1985) Isolation of chloroplast envelopes from Chlamydomonas. Lipid and polypeptide composition. Plant Sci 41: 97-104

Mock T, Gradinger R (1999) Determination of Arctic ice algal production with a new in situ incubation technique. Mar Ecol Prog Ser 177:15-26

Morris I, Glover HE, Yentsch CS (1974) Products of photosynthesis by marine phytoplankton: the effect of environmental factors on the relative rates of protein synthesis. Mar Biol 27:1-9

Opute FI (1974) Lipid and fatty-acid composition of diatoms. J Exp Bot 25(87):823-835

Palmisano AC, Sullivan CW (1982) Physiology of sea ice 
diatoms. I. Response of three polar diatoms to a simulated summer-winter transition. J Phycol 18:489-498

Palmisano AC, Sullivan CW (1985) Pathways of photosynthetic carbon assimilation in sea-ice microalgae from McMurdo Sound, Antarctica. Limnol Oceanogr 30: 674-678

Palmisano AC, Lizotte MP, Smith GA, Nichols PD, White DC, Sullivan CW (1988) Changes in photosynthetic carbon assimilation in antarctic sea-ice diatoms during spring bloom: variation in synthesis of lipid classes. J Exp Mar Biol Ecol 116:1-13

Pohl P, Zurheide F (1979) Fatty acids and lipids of marine algae and the control of their biosynthesis by environmental factors. In: Hoppe HA, Levring T, Tanaka Y (eds) Marine algae in pharmaceutical science. Walter de Gruyter, Berlin, p 473-523

Shifrin NS, Chisholm SW (1981) Phytoplankton lipids: interspecific differences and effects of nitrate, silicate and light-dark cycles. J Phycol 17:374-384

Siegenthaler PA, Rawyler A, Giroud C (1987) Spatial organization and functional roles of acyl lipids in thylakoid membranes. In: Stumpf PK, Mudd JB, Nes WD (eds) The metabolism, structure and function of plant lipids. Plenum Press, New York, p 161-168

Smetacek V (1996) Biodiversity and production in the water mass. In: Hempel G (ed) The oceans and the poles. Gustaf Fischer Verlag, Jena, p 207-216

Smith AE, Morris I (1980) Synthesis of lipid during photosynthesis by phytoplankton of the Southern Ocean. Science 207:197-199

Smith REH, Herman AW (1992) In situ patterns of intracellular photosynthate allocation by sea ice algae in the Canadian High Arctic. Polar Biol 12:545-551

Smith REH, Clement P, Cota GF, Li WKW (1987) Intracellular photosynthate allocation and the control of Arctic marine ice algal production. J Phycol 23:124-132

Smith REH, Clement P, Head E (1989) Biosynthesis and photosynthate allocation patterns of Arctic ice algae. Limnol Oceanogr 34(3):591-605

Smith REH, Harrison WG, Harris LR, Herman AW (1990) Vertical fine structure of particulate matter and nutrients in sea ice of the high Arctic. Can J Fish Aquat Sci 47: $1348-1355$

Smith REH, Cavaletto JF, Eadie BJ, Gardner WS (1993) Growth and lipid composition of high Arctic ice algae during the spring bloom at Resolute, Northwest Territories, Canada. Mar Ecol Prog Ser 97:19-29

Smith REH, Gosselin M, Taguchi S (1997) The influence of major nutrients on the growth and physiology of high arctic ice algae. J Mar Syst 11:63-70

Editorial responsibility: Otto Kinne (Editor), Oldendorf/Luhe, Germany
Smith WO Jr, Barber RT, Huntsman SA (1977) Primary production off the coast of northwest Africa: excretion of dissolved organic matter and its heterotrophic uptake. DeepSea Res 24:35-47

Sommer U (1986) Nitrate- and silicate-competition among antarctic phytoplankton. Mar Biol 91:345-351

Sommer U (1991) Comparative nutrient status and competitive interactions of two Antarctic diatoms (Corethron criophilum and Thalassiosira antarctica). J Plankton Res 13: $61-75$

Sullivan CW, Palmisano AC (1981) Sea-ice microbial communities in McMurdo Sound. Antarct J US 16(5):126-127

Sullivan CW, Palmisano AC, Kottmeier S, Grossi McGS, Moe $R$ (1985) The influence of light on growth and development of the sea-ice microbial community of McMurdo Sound. In: Siegfried WR, Condy PR, Laws RM (eds) Antarctic nutrient cycles and food webs. Springer Verlag, Berlin, p 78-83

Syvertsen EE, Kristiansen S (1993) Ice algae during EPOS, leg 1: assemblages, biomass, origin and nutrients. Polar Biol 13:61-65

Tadros MG, Johansen JR (1988) Physiological characterization of six lipid-producing diatoms from the southeastern United States. J Phycol 24:445-452

Taguchi S, Smith REH (1997) Effects of nitrogen and silicate enrichment on photosynthate allocation by ice algae from Resolute Passage, Canadian Arctic. J Mar Syst 11:53-61

Throndsen J (1970) Flagellates in Arctic waters. Nytt Mag Bot $17: 49-57$

Throndsen J (1974) Planktonic choanoflagellates from North Atlantic waters. Sarsia 56:95-122

Tillmann U, Baumann MEM, Aletsee L (1989) Distribution of carbon among photosynthetic end products in the bloomforming Arctic diatom Thalassiosira antarctica COMBER. Polar Biol 10:231-238

Utermöhl H (1958) Zur Vervollkommnung der quantitativen Phytoplankton-Methodik. Mitt Int Ver Theor Angew Limnol 9:1-38

von Quillfeld CH (1997) Distribution of diatoms in the Northeast Water Polynia, Greenland. J Mar Syst 10:211-240

von Storch HA, Drebes G (1964) Entwicklungsgeschichtliche Untersuchungen an zentrischen Diatomeen. IV. Die Planktondiatomee Stephanopyxis turris, ihre Behandlung und Entwicklungsgeschichte. Helgol Wiss Meeresunters 11:209-257

Williams PJ, Yentsch CS (1976) An examination of photosynthetic production, excretion of photosynthetic products and heterotrophic utilization of dissolved organic compounds with reference to results from a coastal subtropical sea. Mar Biol 35:31-40

Submitted: September 7, 1999; Accepted: March 24, 2000

Proofs received from author(s): August 1, 2000 